\begin{tabular}{|c|l|}
\hline Title & Captopril suppresses inflammation in endotoxin-induced uveitis in rats \\
\hline Author(s) & $\begin{array}{l}\text { Ilieva, Iliyana; Ongami, Kazuhiro; Jin, Xue Hai; Suzuki, Y ukari; Shiratori, Kenji; Y oshida, Kazuhiko; Kase, Satoru; } \\
\text { Ohno, Shigeaki }\end{array}$ \\
\hline Citation & $\begin{array}{l}\text { Experimental Eye Research, 83(3), 651-657 } \\
\text { https://doi.org/10.1016/.exer.2006.03.005 }\end{array}$ \\
\hline Issue Date & 2006-09 \\
\hline Doc URL & http://hdl.handle.net/2115/14735 \\
\hline Type & article (author version) \\
\hline File Information & EER83-3.pdf \\
\hline
\end{tabular}

Instructions for use 


\section{Captopril suppresses inflammation in endotoxin-induced uveitis in}

rats

Iliyana Ilieva, Kazuhiro Ohgami, Xue-Hai Jin, Yukari Suzuki, Kenji Shiratori,

Kazuhiko Yoshida, Satoru Kase and Shigeaki Ohno

Department of Ophthalmology and Visual Sciences, Hokkaido University Graduate

School of Medicine, N15 W7, Kita-ku, Sapporo 060-8638, Japan.

Condensed title: The anti-inflammatory effect of captopril

Key words: Captopril, rennin-angiotensin system, uveitis, anti-inflammatory agent.

Correspondence: Iliyana Ilieva

Department of Ophthalmology and Visual Sciences, Hokkaido University Graduate

School of Medicine, N17 W5, Kita-ku, Sapporo, 060-8638 Japan 
e-mail: achibobo@yahoo.com

Fax: $\quad$ 81-11-736-0952

TEL: $\quad$ 81-11-706-5944 


\section{ABSTRACT}

Captopril is an inhibitor of angiotensin-converting enzyme (ACE) that is largely used

in the treatment of cardiovascular diseases. Several previous studies have demonstrated that captopril exhibits a wide variety of biological activities, including an anti-inflammatory action, on which we focused our attention. The aim of the present study was to investigate the efficacy of captopril on endotoxin induced uveitis (EIU) in rats. We investigated its effect upon cellular infiltration and protein leakage, as well as on the concentration of tumor necrosis factor- $\alpha$ (TNF- $\alpha$ ), nitric oxide (NO), prostaglandin E2 (PGE2), monocyte chemoattractant protein-1 (MCP-1) in the anterior chamber. In addition, we checked its effect on activation of nuclear factor kappa B $(\mathrm{NF}-\kappa \mathrm{B})$ in iris and ciliary body (ICB) cells in vivo.

EIU was induced in male Lewis rats by a footpad injection of lipopolysaccharide (LPS). One hour after the LPS inoculation, either $1 \mathrm{mg} / \mathrm{kg}, 10 \mathrm{mg} / \mathrm{kg}$ or $100 \mathrm{mg} / \mathrm{kg}$ captopril were injected intravenously. 24 hours later, the aqueous humor was collected from both eyes, and the number of infiltrating cells and protein concentration in the aqueous humor were determined. Levels of TNF- $\alpha$, PGE2, NO and MCP-1 were 
determined by enzyme-linked immunosorbent assay. On some eyes, after enucleation,

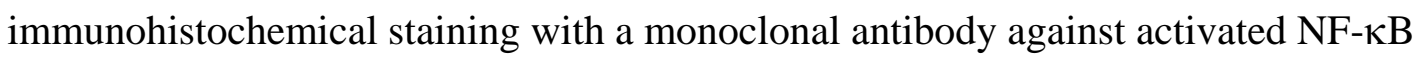
was performed.

Captopril treatment significantly decreased the inflammatory cells infiltration, the level of protein, concentrations of TNF- $\alpha$, PGE2, NO and MCP-1 in the aqueous humor. The number of activated NF-kB-positive cells was lower in ICB of the rats treated with captopril 3 hours after the LPS injection.

The present results indicate that captopril suppresses the inflammation in EIU by

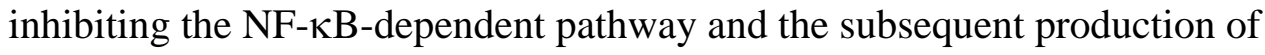
pro-inflammatory mediators.

\section{Introduction}

Captopril([S]-1-[3-mercapto-2-methyl-1-oxo-propyl]-L-proline) is the first marketed orally active angiotensin-converting enzyme (ACE) inhibitor designed to treat hypertension by blocking the conversion of angiotensin I (Ang I) into angiotensin II (Ang II) (Cushman et al., 1977; Ondetti et al., 1977; 
Cushman and Ondetti, 1999). It is widely used in the treatment of cardiovascular diseases, including high blood pressure, heart failure, coronary artery diseases, renal failure. Recently in the light of quickly emerging data on the variety of properties that local rennin-angiotensin system (RAS) and mainly Ang II exert in peripheral tissues, an interest in finding new therapeutic effects of the ACE inhibitors beyond the regulation of homeostasis arose. Captopril has been clearly shown to express immune regulating and anti-inflammatory properties. ACE inhibitors including captopril have proven to be beneficial in experimental autoimmune encephalomyelitis (Constantinescu et al., 1995), myocarditis (Godsel et al., 2003), adriamycin-induced myocardial and hematological toxicities (O. Al-Shabanah et al., 1998), Freund`s adjuvant arthritis (Agha and Mansour, 2000) and experimental rats`colitis (Jahovic et al., 2005). The ability of captopril to act as a reactive oxygene species (ROS) scavenger (Mira et al., 1993) was found to be of major importance in its protection against ischemia-reperfusion-induced arrhythmias (Birincioglu et al, 1997) and liver injury in rats (Gulluoglu et al., 1996). An anti-tumor, antifibrotic 
and cytoprotective effects of captopril have also been demonstrated (Williams et al., 2005; Regan et al., 1996; Murley et al., 2004).

The circulating RAS through its main effector Ang II plays a well-known role in the control of blood pressure, renal haemodynamics and homeostasis. Ang II is an octapeptide that has also been shown to play a key role in inflammation, cell growth, fibrosis in different tissues and cell lines including heart, vessels and kidney. It regulates the inflammatory response by production of pro-inflammatory mediators like cytokines, chemokines (Luft et al., 1999), adhaesion molecules (Pueyo et al., 2000) and reactive oxygen species (Harrison et al., 2003, Bataller et al., 2003) and is thus considered to be a true cytokine (Ruiz-Ortega et al., 2001). Ang II can directly activate immune cells and regulate their functions inducing chemotaxis, proliferation, differentiation and phagocytosis (Mattana et al., 1995; Ruiz-Ortega et al., 2001; Suzuki et al., 2002; Ruiz-Ortega and Ortiz, 2005). Immune cells express all the components of RAS and can produce angiotensinogen (Gomez et al., 1993; Okamura et al., 1999). RAS components have been identified in human ciliary body and 
aqueous humor (Cullinane et al., 2002) and involvement of RAS in ocular inflammation has been suggested by Nagai et al (Nagai et al., 2005), who proved the suppression of endotoxin-induced uveitis (EIU) by an angiotensin II type 1 receptor (AT1-R) inhibition.

Among the intracellular signals involved in Ang II-induced

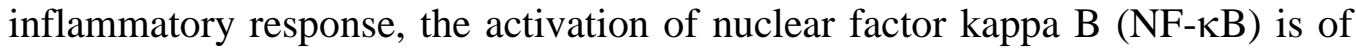
special interest (Ruiz-Ortega et al., 2001). NF-кB is a ubiquitous transcription factor with high reactivity potential that is most extensively exploited by immune cells (Baurel and Henkel, 1994). As a primary transcription factor NF-кB responds directly to numerous extracellular stimuli (including lipopolysaccharide (LPS), reactive oxygen species (ROS) and AngII), rapidly transferring the external information via cytoplasmic/nuclear signaling to DNA where it positively regulates the expression of genes involved in the inflammatory and immune responses, including expression of tumor necrosis factor- $\alpha$ (TNF- $\alpha$ ) (Collart et al, 1990; Shakhov et al., 1990; Baurel and Henkel, 1994), monocyte chemoattractant protein -1 (MCP-1), nitric oxide synthase 
(NOS), cyclooxygenase-2 and angiotensinogen (Barnes, Karin, 1997; Guijarro, Egido, 2001). Interference in NF- $\kappa \mathrm{B}$ activation is proved to have beneficial effect in suppressing acute inflammatory processes. A significant upregulation of activated NF- $\mathrm{BB}$ in the iris and ciliary body (ICB) during EIU has been demonstrated (Ohta et al., 2002). Inhibition of NF-кB signaling pathway by astaxanthin, a carotenoid with antioxidant effects, leads to suppression of EIU in rats (Suzuki et al., 2005).

The EIU, which serves as an animal model for acute anterior ocular inflammation in humans, is induced by a systemic injection of a sublethal dose of LPS - an outer membrane component of Gram- negative bacteria and a potent activator of monocytes and macrophages (Rosenbaum et al, 1980). EIU is characterized by percolation of proteins from the serum and by infiltration of macrophages and neutrophils into the eye ( $\mathrm{Li}$ et al, 1995). In Lewis rats with EIU, acute inflammation develops mainly in the anterior chamber (iridocyclitis) and inflammatory cells may also infiltrate the vitreous and retina (Tuaillon et al., 2002). In general, EIU peaks 24 hours after LPS injection and subsides within 
the next 96 hours.

LPS triggers the secretion of a variety of inflammatory mediators, such

as TNF- $\alpha$ (Tracey and Cerami, 1994), prostaglandin E2 (PGE2) (Bellot et al, 1996); Murakami et al, 2000), MCP-1 (Tuaillon et al, 2002), as well as the generation of ROS and excessive amounts of nitric oxide (NO) (Nathan and Xie, 1994), which all contribute to the pathophysiology of septic shock. The transcription of a significant number of these inflammatory mediators is triggered by the intracellular activation of NF-кB.

In the present study we focused our attention on captopril`s anti-inflammatory action and we investigated its effect on several well-described inflammatory markers in EIU.

\section{Materials and Methods}

Animal groups and EIU

Six-week-old male Lewis rats were used. The rats weighed 220 - 250 g. EIU was 
induced by footpad injections of $200 \mu \mathrm{g}$ of LPS (100 $\mu$ g each footpad) from Salmonella typhimurium (Sigma, MO, USA) that had been diluted in $0.1 \mathrm{ml}$ of phosphate buffered saline (pH7.4, PBS).

Rats were injected intravenously with $1 \mathrm{mg} / \mathrm{kg}, 10 \mathrm{mg} / \mathrm{kg}$ or $100 \mathrm{mg} / \mathrm{kg}$ of captopril (Calbiochem, CA, USA), diluted in $0.1 \mathrm{ml}$ of PBS containing $0.1 \%$ dimethyl sulfoxide (DMSO, Sigma, MO, USA). The intravenous injection was administered 60 minutes after the LPS stimulation. For the LPS group and the control group, only PBS containing 0.1\% DMSO was administered intravenously using the same schedule as for the captopril administered groups.

24 hours after the LPS injection, the rats were sacrificed and the aqueous humor (15-20 $\mu \mathrm{l} /$ rat) was collected from both eyes by an anterior chamber paracentesis using a 30 gauge needle.

Number of anterior chamber cells and protein concentration

For cell counting, the aqueous humor sample was suspended in an equal amount of Türk stain solution, and the cells were counted using a hemocytometer under a light 
microscope; the number of cells per field (an equivalent of $0.01 \mathrm{ml}$ ) was manually

counted, and the number of cells per microliter was obtained by averaging the results of

four fields from each sample.

The total protein concentration in the aqueous humor was determined by BCA protein assay reagent kit (Pierce, Rockford, IL, USA).

The levels of TNF- $\alpha$, PGE2 and MCP-1

The levels of TNF- $\alpha$, PGE2 and MCP-1 concentration in aqueous humor were measured by ELISA (R\&D systems, MN, USA) according to the manufacturer's instruction. The ELISA assays were carried out in duplicate.

Determination of nitrite concentration in the aqueous humor

NO was measured as its end product, nitrite, by using Griess reagent as described elsewhere (Sigma, MO, USA). The culture supernatant (100 $\mu \mathrm{l}$ ) was mixed with $100 \mu \mathrm{l}$ of Griess reagent for $10 \mathrm{~min}$, and the absorbance at $550 \mathrm{~nm}$ was measured in a microplate reader. The concentration of nitrite in the samples was determined with 
reference to a sodium nitrite standard curve. The data represent the mean of 8 rats \pm SD.

Immunohistochemical studies for NF- $\mathrm{B}$

Three hours after the LPS injection, rats were anesthetized with pentobarbital sodium (30 $\mathrm{mg} / \mathrm{kg}$ ) and the eyes were fixed by an intracardiac perfusion of $4 \%$ paraformaldehyde in 0.1 M PBS. The eyes were enucleated and immersed in the same fixative for 12 hours. After dehydration and paraffin embedment of the eyes, $5 \mu \mathrm{m}$ sagittal sections near the optic nerve head were obtained, slices were rinsed twice in PBS and incubated with normal goat serum, followed by p65 antibody (Santa Cruz, c-20, CA, USA). Binding of the primary antisera was localized using Cy-3 conjugated goat anti-rabbit IgG (Jackson ImmunoResearch Laboratories, Inc, West Grove, PA, USA). Nuclei were then stained with PBS containing YO-PRO-1 (Molecular Probes, Eugene, OR, USA) for 5 min. The sections were examined by laser scanning confocal microscopy (MRC-1024: Bio-Rad, Richmond, CA, USA; and LSM 510: Carl Zeiss, Oberkochen, Germany). Within each ICB sample, two areas were randomly photographed and the number of activated NF-kB positive cells (NF- $\kappa \mathrm{B}$ having entered 
the nuclei resulted in changing green nuclei color into orange) was counted by a masked researcher. The results were averaged for each sample and in each group. This analysis was performed in the six eyes of three rats in each group.

Statistical Analysis

The results were expressed as mean \pm S.D. All data were analyzed by analysis of variance (ANOVA), followed by Scheffe`s test for multiple comparing. A p value lower than 0.05 was considered statistically significant.

\section{Results}

Number of inflammatory cells and protein concentration in aqueous humor

In the LPS group, the number of inflammatory cells in aqueous humor 24 hours after

LPS treatment was $102.9 \pm 15.1 \times 10^{5}$ cells/ml $($ mean $\pm \mathrm{SD}, \mathrm{n}=8)$ and the protein concentration was $49.1 \pm 8.7 \mathrm{mg} / \mathrm{ml}$. The groups treated with captopril showed very significantly reduced numbers of inflammatory cells (captopril $1 \mathrm{mg} / \mathrm{kg}: 3.1 \pm 3.6$ x $10^{5}$ cells/ml; captopril 10 mg/kg: $0.8 \pm 0.6$ x 10 $10^{5}$ cells/ml; captopril 100 mg/kg: $0.8 \pm 0.6$ x 
$10^{5}$ cells/ml) compared to the LPS group ( $\mathrm{p}<0.01$, Fig. 1a) and protein concentration $(1 \mathrm{mg} / \mathrm{kg}: 17.2 \pm 4.4 \mathrm{mg} / \mathrm{ml}, \mathrm{p}<0.01 ; 10 \mathrm{mg} / \mathrm{kg}: 13 \pm 3.7 \mathrm{mg} / \mathrm{ml} ; 100 \mathrm{mg} / \mathrm{kg}: 8.6 \pm 1.9$ mg/ml; Fig.1b). No infiltrating cells were detected in aqueous humor of non-LPS treated rats (control group) and the level of protein detectable was $2.9 \pm 1.5 \mathrm{mg} / \mathrm{ml}$ $(n=8)$.

TNF- $\alpha$, PGE2 and nitrite concentrations in aqueous humor In the aqueous humor of the control group of rats TNF- $\alpha$ was not detected. In the LPS group its concentration reached $1.2 \pm 0.5 \mathrm{ng} / \mathrm{ml}$, while captopril groups showed a significant reduction in the TNF- $\alpha$ levels $(1 \mathrm{mg} / \mathrm{kg}$ captopril: $0.1 \pm 0.1 \mathrm{ng} / \mathrm{ml}(\mathrm{p}<0.01)$, in the $10 \mathrm{mg} / \mathrm{kg}$ captopril and $100 \mathrm{mg} / \mathrm{kg}$ captopril treated groups TNF- $\alpha$ was not detectable (Fig. 2a). The concentration of PGE2 in the control group was $0.4 \pm 0.1 \mathrm{ng} / \mathrm{ml}$ and in the LPS group it was increased to 9.6+ $4.4 \mathrm{ng} / \mathrm{ml}$. PGE2 levels were also significantly reduced by captopril: $1 \mathrm{mg} / \mathrm{kg}$ captopril: $0.4 \pm 0.2 \mathrm{ng} / \mathrm{ml}(\mathrm{p}<0.01) ; 10 \mathrm{mg} / \mathrm{kg}$ captopril: $0.4 \pm 0.2 \mathrm{ng} / \mathrm{ml} ; 100 \mathrm{mg} / \mathrm{kg}$ captopril: $0.3 \pm 0.1 \mathrm{ng} / \mathrm{ml}$, (Fig.2b). The content of nitrite in the aqueous humor of control rats was $7.8 \pm 3.4 \mu \mathrm{M}$ and it rose about 20 fold 
in the LPS group (156.6 $+25.4 \mu \mathrm{M}, \mathrm{p}<0.01)$. Nitrite levels in the aqueous humor 24 hours after captopril treatment were: $1 \mathrm{mg} / \mathrm{kg}$ captopril: $90.7 \pm 15.8 \mu \mathrm{M}, \mathrm{p}<0.01 ; 10$

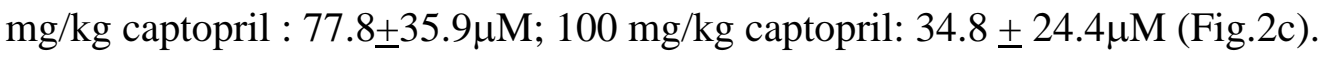

MCP-1 in aqueous humor

No MCP-1 was detected in the control group of rats while in the LPS group the MCP-1 level was 13.4_1.2 pg/ml (Fig.3). Captopril groups had significantly $(\mathrm{p}<0.01)$ reduced levels of MCP-1 (1 mg/kg captopril: 6.1_1.3 pg/ml; 10 mg/kg captopril: $1.0 \pm 0.5 \mathrm{pg} / \mathrm{ml} ; 100 \mathrm{mg} / \mathrm{kg}$ captopril: $0.5 \pm 0.1 \mathrm{pg} / \mathrm{ml})$.

Suppression of NF- $\kappa$ B activation in ICB

No activated NF-кB-positive nuclei were found in the ICB of normal controls (Fig. 4 Aa, 4B). Three hours after injection of LPS activated NF-кB p65 was strongly expressed in the ICB of the LPS group (42.7+3.2\%, Fig. 4Ab, 4B). In contrast, the

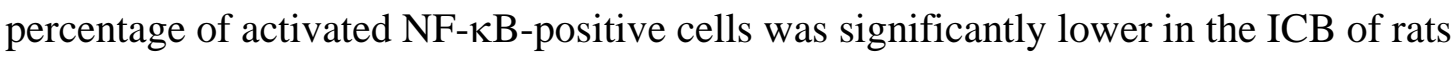
treated with 100mg/kg captopril (13.1+5.4\% ( $<<0.01)$, (Fig. 4Ac, 4B). The groups

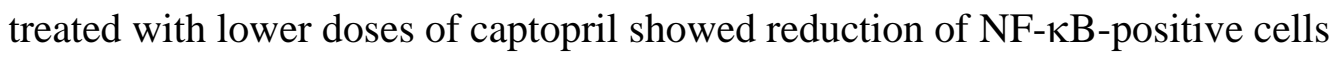


percentage (1mg/kg: 31.1+6.4\%; 10mg/kg: 29.8+11.3\%), which was not significant (Fig. 4B).

\section{Discussion}

The results of this study suggest that the ACE-inhibitor captopril has a strong anti-ocular inflammatory effect in EIU. We demonstrated for the first time that

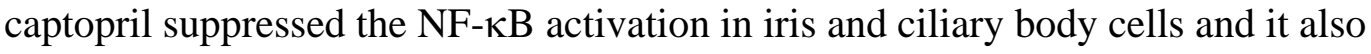
drastically lowered leucocyte infiltration, protein leakage and certain other inflammatory markers (TNF- $\alpha$, PGE-2, MCP-1, NO) in aqueous humor in a dose-dependant manner.

The exact mechanism by which captopril suppresses EIU is yet to be established, but our results support the findings that it acts via interfering with NF- $\mathrm{B}$ pathway activation most probably by blocking the local Ang II production. The specific down-regulation of ACE by captopril has been demonstrated in human dendritic cells and its inhibitory properties have been attributed to its structure containing thiol groups that provide specific binding to ACE as well as to indirect suppression of expression of

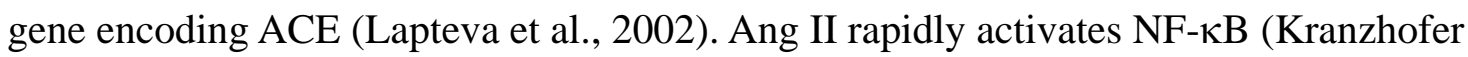


et al., 1999) through angiotensin II type 1 (AT-1) and angiotensin II type 2 (AT-2)

receptors (De Gasparo et al., 2000; Murphy et al., 1991). Ang II stimulation upregulates PYRIN mRNA (the family member of PYRIN- containing Apaf-1-like proteins) that participates in inflammatory cell signaling by regulating the activation of NF- $\mathrm{BB}$ and cytokine processing (Steinman, 1988; Wang et al, 2002). Reactive oxygen species are regarded as second messengers in NF- $\kappa \mathrm{B}$ activation and cytokine expression (Schreck et al., 1991; Satriano et al., 1993). Ang II stimulates ROS production thus activating different nuclear responses (Puri et al., 1995; Griending and Ushio-Fukai, 2000; Saito and Berk, 2002). A possible mechanism of protecting the NF-kB activation and inflammatory cascade generation by captopril is the scavenging of ROS.

$\mathrm{NF}-\kappa \mathrm{B}$ is comprised of a family of proteins that bind as homo- or heterodimers to $\kappa \mathrm{B}$-enhancing elements in promotor regions of selected genes. These include RelA (p65), RelB, c-Rel, p52, p50. Under normal conditions in most cells NF- $\kappa \mathrm{B}$ is found in an inactive form in the cytoplasm, bound to the inhibitory I $\kappa \mathrm{B}$ protein. Upon stimulation by a wide variety of signals including LPS and Ang II, NF- $\mathrm{B}$ moves into the nucleus where it triggers the various pro-inflammatory genes 
transcription. Our immunohistochemical experiment demonstrated that LPS induced p65 nuclear translocation was significantly prevented in the ICB by the high dose captopril. It also showed a tendency towards reduction in the lower-concentration treated groups, but the results did not differ significantly from the LPS group.

TNF- $\alpha$ is a 185 amino acid glucoprotein cytokine that plays a leading role in activation and sustaining inflammatory responses. It is shown to stimulate inflammatory cells recruitment, synthesis of cytokines, eicosanoids and NO. It has recently been reported that symptoms of Behcet's disease uveitis had remarkably been ameliorated by administration of anti-TNF- $\alpha$ antibody (Ohta et al., 2004). The transcription of TNF- $\alpha$ is under NF-kB control and there is a positive loop, amplifying the cytokine cascade during inflammation as TNF- $\alpha$ is also found to activate NF- $\mathrm{BB}$ (Baurele and Henkel, 1994; Baldwin, 1996; Barnes and Karin, 1997). It has previously been established that ACE inhibitors suppress TNF- $\alpha$ synthesis in vivo and in vitro (Fukuzawa et al., 1997) and in this study captopril successfully down-regulated TNF- $\alpha$ in the aqueous humor, most probably by interfering in the generation of the positive loop between TNF- $\alpha$ and NF-kB, confirming its anti-inflammatory properties in the eye also. 
We investigated the concentration of PGE2 and NO in aqueous humor, which

were also significantly down-regulated by captopril treatment. Both PGE2 and NO have a profound effect on local inflammatory processes mainly by vascular permeability regulation and they have been shown to contribute to the breakdown of blood-aqueous barrier in uveitis (Smith et al., 1998, Tilton et al., 1994). The expression of the inducible enzymes, responsible for their synthesis (COX-2 and iNOS respectively), is also controlled by NF-кB. Bellot et al (Bellot et al., 1996) reported that PGE2 and NO have an additive effect in EIU in rabbits and that inhibition of both pathways would improve the therapeutic management of uveitis. Therefore our data suggest that the suppressed ocular inflammation can be attributed in part to the down-regulation of these mediators by captopril.

Similarly, another inflammation marker, which we measured, MCP-1, is also under NF-кB control. MCP-1 is an important mediator of monocyte infiltration (Gu et al., 1999) and is shown to be over-expressed in human eyes during acute anterior uveitis (Verma et al., 1997) as well as in the rat EIU model (de Vos et al., 1994). The results of this study show that captopril successfully down-regulates MCP-1 levels in anterior 
chamber, thus showing its anti-inflammatory properties also by affecting monocyte

recruitment in EIU.

The present study shows that captopril is capable of suppressing EIU in rats.

There has been a continuous search for new anti-ocular inflammatory drugs as the most effective and widely exploited corticosteroids show numerous adverse effects in their prolonged clinical usage in treating inflammatory conditions. Our data suggest that captopril can be addressed as a promising agent for the treatment of ocular inflammation. Further investigations on captopril as well as on other ACE inhibitors in acute (EIU) and chronic uveitis models (experimental autoimmune uveitis) are appealing to us.

\section{References}

Agha AM, Mansour M, 2000, Effects of Captopril on interleukin-6, leucotriene B(4), and oxidative stress markers in serum and inflammatory exudates of arthritic rats: evidence of anti-inflammatory activity. Toxicol Appl Pharmacol, 168, 123-30

Al-Shabanah O, Mansour m, el-Kashef H, al-Belkairi A, 1998, Captopril ameliorates 
myocardial and hematological toxicities induced by adriamycin. Biochem Mol Biol Int, 45, 419-27

Baldwin AS Jr, 1996, The NF-kappa B and I kappa B proteins: new discoveries and insights. Annu Rev Immunol. 14:649-83

Barnes PJ, Karin M, 1997, Barnes PJ \& Karin M: Nuclear factor-kappa B: A pivotal transcription factor in chronic inflammatory diseases, N Engl J Med. 336, 1066-71

Bataller R, Schwalbe Rf, Choi YH, Yang L, Paik YH, Lindquist J, Qian T, Schoonhoven R, Hagedorn CH, Lemasters JJ, Brenner DA, 2003, NADPH oxidase signal transduces angiotensin II in hepatic stellate cells and is critical in hepatic fibrosis. J Clin Invest 112, 1383-94

Baurel PA, Henkel T, 1994, Function and activation of NF-kappa B in the immune system, Annu Rev Immunol. 12,141-79.

Bellot, J. L., Palmero, M., Garcia-Cabanes, C., Espi, R., Hariton, C., and Orts, A. 1996. Additive effect of nitric oxide and prostaglandin-E2 synthesis inhibitors in endotoxin-induced uveitis in the rabbit. Inflamm Res 45, 203-8. 
Birincioglu M, Aksoy T, Olmez E, Acet A, 1997, Protective effect of ACE inhibitors on ischemia-reperfusion-induced arrhythmias in rats: is this effect related to the free radical scavenging action of these drugs? Free Radic Res, 27, 389-96

Collart MA, Baurele P, Vassali P, 1990, Regulation of tumor necrosis factor alpha transcription in macrophages: involvement of four kappa B-like motifs and of constitutive and inducible forms of NF-kappa B, Mol Cell Biol, 10, 1498-506.

Constantinescu CS, Ventura E, Hilliard B, Rostami A, 1995, Effects of the angiotensin converting enzyme inhibitor captopril on experimental autoimmune encephalomyelitis. Immunopharmacol immunotoxicol, 17, 471-91

Cullinane AB, Leung PS, Ortego J, Coca-Prados M, Harvey BJ, 2002, Renin-angiotensin system expression and secretory function in cultured human ciliary body non-pigmented epithelium, Br J Ophthalmol, 86, 676-83

Cushman DW, Cheung HS, Sabo EF, Ondetti MA, 1977, Design of potent competitive inhibitors of angiotensin-converting enzyme. Carboxyalkanoyl and mercaptoalkanoyl amino acids, Biochemistry 16, 5484-91

Cushman DW, Ondetti MA, 1999, Design of angiotensin converting enzyme inhibitors. 
Nat Med, 5, 1110-3

De Gasparo M, Catt KJ, Inagami T, Wright JW, Unger T, 2000, International union of pharmacology. XXIII. The angiotensin II receptors. Pharmacol Rev. 52, 415-72

De Vos AF, Klaren VN, Kijlstra A, 1994, Expression of multiple cytokines and IL-1RA in the uvea and retina during endotoxin-induced uveitis in the rat. Invest Ophthalmol Vis Sci. 35, 3873-83

Fukuzawa M, Satoh J, Sagara M, Muto G, Muto Y, Nishimura S, Miyaguchi S, Qiang XL, Sakata Y, Nakazawa T, Ikehata F, Ohta S, Toyota T, 1997, Angiotensin converting enzyme inhibitors suppress production of tumor necrosis factor-alpha in vitro and in vivo. Immunopharmacology. 36, 49-55.

Godsel LM, Leon JS, Wang K, Fornek JL, Molteni A, Engman DM, 2003, Captopril prevents experimental autoimmune myocarditis. J Immunol, 171, 346-52

Gomez RA, Norling LL, Wilfong N, Isakson P, Lynch KR, Hock R, Quesenberry P, 1993, Leucocytes synthesize angiotensinogen, Hypertension, 21, 470-5

Griendling KK, Ushio-Fukai M, 2000, Reactive oxygen species as mediators of angiotensin II signaling. Regul Pept, 91, 21-7. 
Gu L, Tseng SC, Rollins BJ, 1999, Monocyte chemoattractant protein-1. Chem Immunol, 72, 7-29.

Guijarro C, Egido J, 2001, Transcription factor-kappa B (NF-kappa B) and renal disease. Kidney Int, 59, 415-24.

Gulluoglu BM, Aktan AO, Yegen C, Kurtel H, Yalin R, 1996, Endothelin release in augmented with captopril in rat ischemia-reperfusion injury of the liver. Res Exp Med (Berl), 196, 227-33

Harrison DG, Cai H, Landmesser U, Griendling KK, 2003, Interractions of angiotensin II with NAD(P)H oxidase, oxidant stress and cardiovascular disease. J Renin Angiotensin Aldosterone Syst, 4, 51-61

Jahovich N, Ercan F, Gedik N, Yuksel M, Sener G, Alican I, 2005, The effect of angiotensin-converting enzyme inhibitors on experimental colitis in rats. Regul Pept, 130, 67-74

Kranzhofer R, Browatzki M, Schmidt J, Kubler W, 1999, Angiotensin II activates the proinflammatory transcription factor nuclear factor-kappaB in human monocytes. Biochem Biophys Res Commun. 257, 826-8. 
Lapteva N, Ide K, Nieda M, Ando Y, Hatta-Ohashi Y, Minami M, Dymshits G, Egawa K, Juji T, Tokunaga K, 2002, Activation and suppression of renin-angiotensin system in human dendritic cells. Biochem Biophys Res Commun, 296, 194-200.

Li, Q., Peng, B., Whitcup, S. M., Jang, S. U., and Chan, C. C. 1995. Endotoxin induced uveitis in the mouse: susceptibility and genetic control. Exp Eye Res, 61, 629-32.

Luft FC, Mervaala E, Muller DN, Gross V, Schmidt F, Park JK, Schmitz C, Lippoldt A, Breu V, Dechend R, Dragun D, Schneider W, Ganten D, Haller H, 1999, Hypertension-induced end-organ damage: A new transgenic approach to an old problem. Hypertension, 33, 212-8

Mattana J, Sankaran RT, Singhal PC, 1995, Repetitive mechanical strain suppresses macrophage uptake of immunoglobulin G complexes and enhances cyclic adenosine monophosphate synthesis. Am J Pathol, 147, 529-40

Mira ML, Silva MM, Querioz Mj, Manso CF, 1993, Angiotensin converting enzyme inhibitors as oxygen free radical scavengers. Free Radic Res Commun, 19, $173-81$ 
Murakami, A., Nakamura, Y., Tanaka, T., Kawabata, K., Takahashi, D., Koshimizu, K., and Ohigashi, H. 2000. Suppression by citrus auraptene of phorbol ester-and endotoxin-induced inflammatory responses: role of attenuation of leukocyte activation. Carcinogenesis, 21, 1843-50.

Murley JS, Kataoka Y, Cao D, Li JJ, Oberley LW, Grdina DJ, 2004, Delayed radioprotection by NFkappaB-mediated induction of Sod2 (MnSOD) in SA-NH tumor cells after exposure to clinically used thiol-containing drugs. Radiat Res, $162,536-46$

Murphy TJ, Alexander RW, Griendling KK, Runge MS, Bernstein KE, 1991, Isolation of a cDNA encoding the vascular type-1 angiotensin II receptor. Nature. 351, 233-6.

Nagai N, Oike Y, Noda K, Urano T, Kubota Y, Ozawa Y, Shinoda H, Koto T, Shinoda K, Inoue M, Tsubota K, Yamashiro K, Suda T, Ishida S, 2005, Suppression of ocular inflammation in endotoxin-induced uveitis by blocking the angiotensin II type 1 receptor, Invest Ophthalmol Vis Sci, 46, 2925-31

Nathan, C., and Xie, Q. W. 1994. Nitric oxide synthases: roles, tolls, and controls. Cell, 
78, 915-8.

Ohta K, Nakayama K, Kurokawa T, Kikuchi T, Yoshimura N, 2002, Inhibitory effects of pyrrolidine dithiocarbamate on endotoxin-induced uveitis in Lewis rats, Invest Ophthalmol Vis Sci. 43, 744-50.

Okamura A, Rakugi H, Onishi M, Yanagitani Y, Takiuchi S, Moriguchi K, Fennessy PA, Higaki J, Ogihara T, 1999, Upregulation of rennin-angiotensin system during differentiation of monocytes to macrophages, J Hypertens, 17, 537-45

Ondetti MA, Rubin B, Cushman DW, 1977, Design of specific inhibitors of angiotensin-converting enzyme: new class of orally active antihypertensive agents. Science 196, 441-4

Pueyo ME, Gonsales W, Nikoletti A Savoie F, Arnal JF, Michel JB, 2000, Angiotensin II stimulates endothelial vascular cell adhesion molecule-1 via nuclear factor-kappaB activation induced by intracellular oxidative stress. Arterioscler Thromb Vasc Biol, 20, 645-51

Puri PL, Avantaggiati ML, Burgio VL, Chirillo P, Collepardo D, Natoli G, Balsano C, Levrero M, 1995, Reactive oxygen intermediates mediate angiotensin II-induced 
c-Jun.c-Fos heterodimer DNA binding activity and proliferative hypertrophic responses in myogenic cells. J Biol Chem. 270, 22129-34.

Regan CP, Anderson PG, Bishop SP, Berecek KH, 1996, Captopril prevents vascular and fibrotic changes but not cardiac hypertrophy in aortic-banded rats. Am J Physiol, 271, H906-13

Rosenbaum, J. T., McDevitt, H. O., Guss, R. B., and Egbert, P. R. 1980. Endotoxin-induced uveitis in rats as a model for human disease, Nature 286, 611-3.

Ruiz-Ortega M, Lorenzo O, Ruperez M, Esteban V, Mezzano S, Egido J, 2001, Renin-angiotensin system and renal damage: emerging data on angiotensin II as a proinflammatory mediator. Contrib Nephrol. (135), 123-37

Ruiz-Ortega M, Lorenzo O, Ruperez M, Esteban V, Suzuki Y, Mezzano S, Plaza JJ, Edigo J, 2001, Role of the rennin-angiotensin system in vascular diseases: expanding the field. Hypertension, 38, 1382-7

Ruiz-Ortega M, Lorenzo O, Ruperez M, Suzuki Y, Egido J, 2001, Angiotensin II activates nuclear transcription factor-kappaB in aorta of normal rats and in 
vascular smooth muscle cells of AT 1 knockout mice, Nephrol Dial Transplant, 16

Suppl 1, 27-33

Ruiz-Ortega M, Ortiz A, 2005, Angiotensin II and reactive oxygen species, Antiox Redox Signal 7, 1258-60

Saito Y, Berk BC, 2002, Angiotensin II-mediated signal transduction pathways, Curr Hypertens Rep, 4, 167-71

Satriano JA, Shuldiner M, Hora K, Xing Y, Shan Z, Schlondorff D, 1993, Oxygen radicals as second messengers for expression of the monocyte chemoattractant protein, JE/MCP-1, and the monocyte colony-stimulating factor, CSF-1, in response to tumor necrosis factor-alpha and immunoglobulin G. Evidence for involvement of reduced nicotinamide adenine dinucleotide phosphate (NADPH)-dependent oxidase. J Clin Invest, 92, 1564-71.

Schreck R, Rieber P, Baeuerle PA, 1991, Reactive oxygen intermediates as apparently widely used messengers in the activation of the NF-kappa B transcription factor and HIV-1. EMBO J, 10, 2247-58.

Shakhov AN, Collart MA, Vassali P, Nedospasov SA, Jongeneel CV, 1990, Kappa 
B-type enhancers are involved in lipopolysaccharide-mediated transcriptional activation of the tumor necrosis factor alpha gene in primary macrophages. $\mathrm{J}$ Exp Med, 171, 35-47.

Smith JR, Hart PH, Williams KA, 1998, Basic pathogenic mechanisms operating in experimental models of acute anterior uveitis. Immunol Cell Biol. 76, 497-512 Steinman R.M, Cytokines amplify the function of accessory cells, 1988, Immunol. Lett. 17, 197-202

Suzuki Y, Ohgami K, Shiratori K, Jin XH, Ilieva I, Koyama Y, Yazawa K, Yoshida K, Kase S, Ohno S, 2005, Suppressive effects of astaxanthin against rat endotoxin-induced uveitis by inhibiting the NF-kappaB signaling pathway, Exp Eye Res. 2005

Suzuki Y, Ruiz-Ortega M, Lorenzo O, Ruperez M, Esteban V, Egido J, 2002, Inflammation and angiotensin II. Int J Biochem Cell Biol, 35, 881-900

Tracey, K. J., and Cerami, A. 1994. Tumor necrosis factor: a pleiotropic cytokine and therapeutic target. Annu Rev Med 45, 491-503.

Tilton RG, Chang K, Corbett JA, Misko TP, Currie MG, Bora NS, Kaplan HJ, 
Williamson JR, 1994, Endotoxin-induced uveitis in the rat is attenuated by inhibition of nitric oxide production. Invest Ophthalmol Vis Sci. 35, 3278-88.

Tuaillon, N., Shen de, F., Berger, R. B., Lu, B., Rollins, B. J., and Chan, C. C. 2002. MCP-1 expression in endotoxin-induced uveitis. Invest Ophthalmol Vis Sci 43, 1493-8.

Verma MJ, Lloyd A, Rager H, Strieter R, Kunkel S, Taub D, Wakefield D, 1997, Chemokines in acute anterior uveitis. Curr Eye Res. 16, 1202-8.

Wang L, Manji G, Grenier J.M, Al-Garawi A, Merriam S, Lora J.M, Geddes B.J, Briskin M, Distefano P.S and Bertin J, 2002, PYPAF7: a novel PYRIN-containing Apaf1-like protein that regulates activation of NF-kB and caspase-1-dependent cytokine processing, J. Biol. Chem. 17, 17.

Williams RN, Parsons SL, Morris TM, Rowlands BJ, Watson SA, 2005, Inhibition of matrix metalloproteinase activity and growth of gastric adenocarcinoma cells by an angiotensin converting enzyme inhibitor in in vitro and murine models. Eur $\mathrm{J}$ Surg Oncol 31, 1042-50 


\section{FIGURE LEGENDS}

Figure 1. Effect of captopril on LPS induced inflammatory cellular infiltration (a) and protein concentration (b) in the aqueous humor. 24 hours after LPS treatment. Each value represents the mean $\pm \mathrm{SD}(\mathrm{n}=8)$.

**Significantly different from LPS group, $(\mathrm{p}<0.01)$.

Figure 2. Effect of captopril on LPS induced TNF- $\alpha$ (a), PGE2 (b) and Nitrite concentration ((c), as a NO measure) in the aqueous humor 24 hours after LPS treatment. Each value represents the mean $\pm \mathrm{SD}(\mathrm{n}=8)$.

**Significantly different from LPS group, $(\mathrm{p}<0.01)$.

Figure 3. Effect of captopril on LPS induced MCP-1 concentration in the aqueous humor 24 hours after LPS treatment. Each value represents the mean \pm SD $(n=8)$.

**Significantly different from LPS group, $(\mathrm{p}<0.01)$.

Figure 4. Effect of captopril on NF-кB p-65 activation in the ICB 3 hours after LPS 


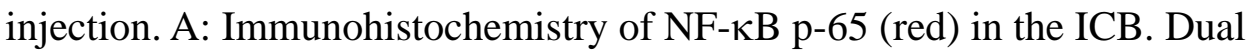
immunofluorescence labeling showed the colocalisation (yellow) in nuclei (green). (a) control group - no LPS treatment. (b) LPS group - rats injected with LPS and 1 hour later with $0.1 \mathrm{ml}$ PBS. (c) captopril-treated group - rats injected with LPS and 1 hour later with $0.1 \mathrm{ml}$ captopril, diluted in PBS (100mg/kg captopril). Magnification: x400. Arrows: activated (NF-kB-positive) cells. B: Quantitative analysis of the percentage of NF-kB-positive cells in ICB. Each value represents the mean \pm SD $(n=3)$.

**Significantly different from LPS group, $(\mathrm{p}<0.01)$. 


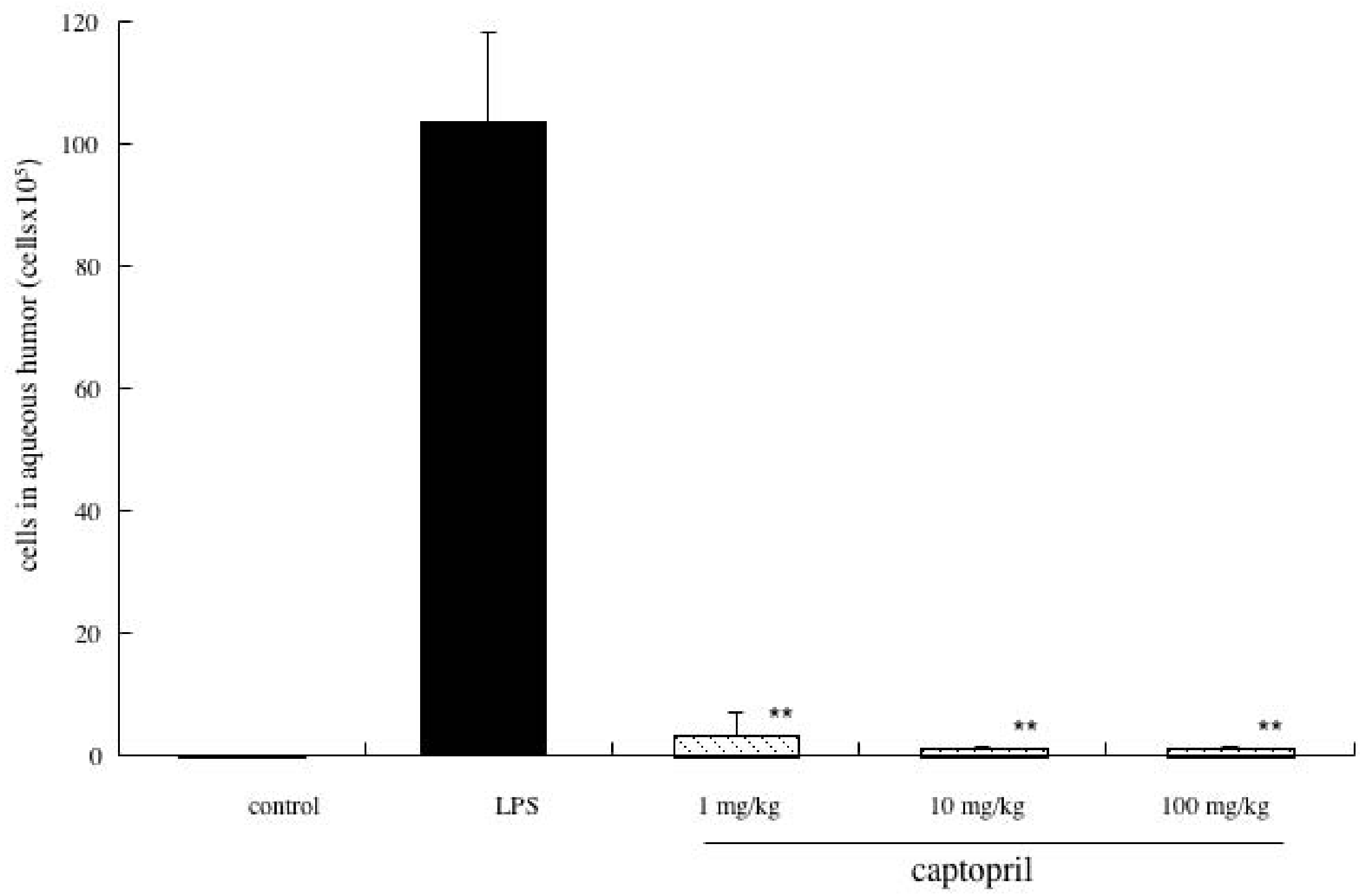

[Fig. 1a Ilieva et al] 


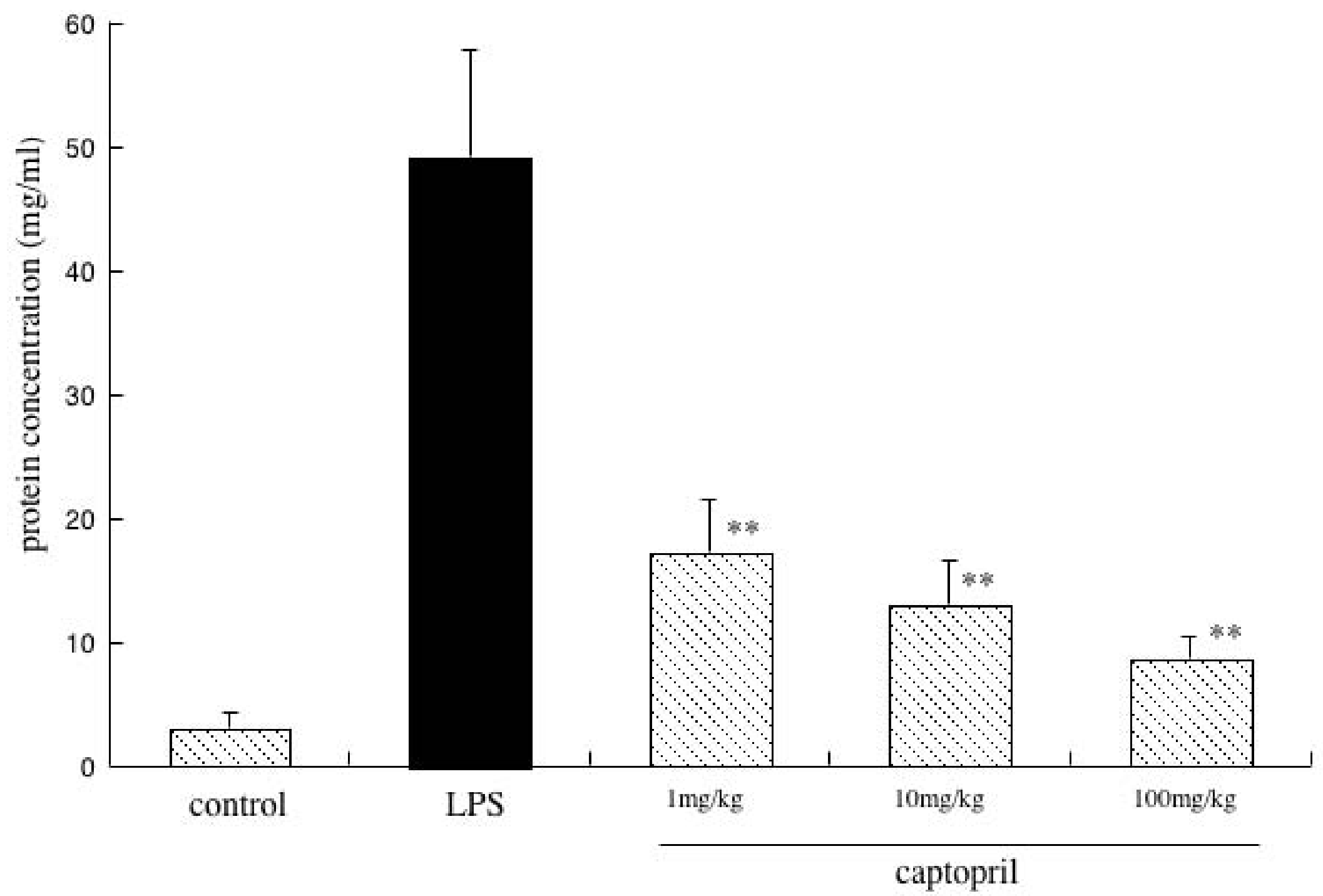

[Fig. 1b Ilieva et al] 


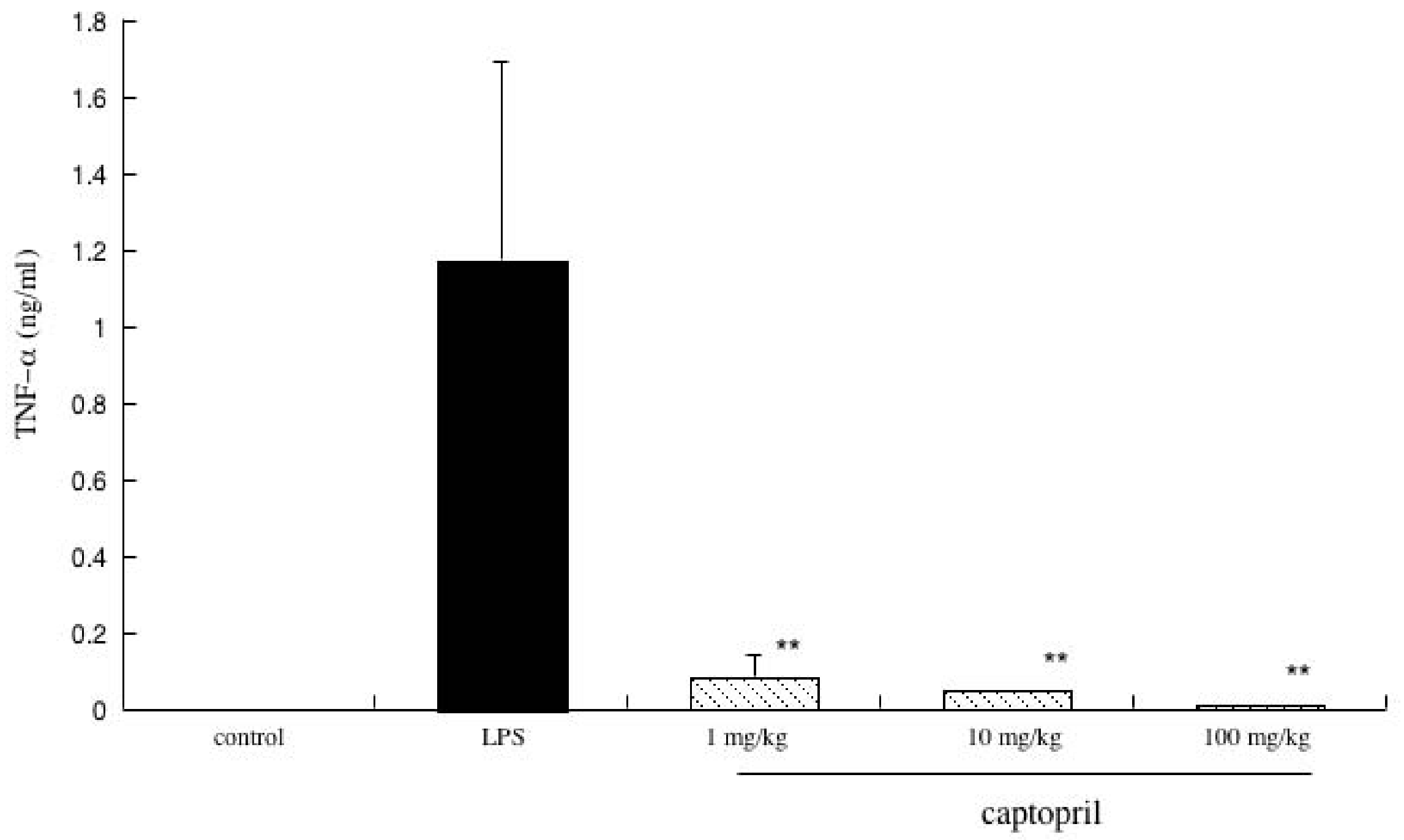

[ Fig. 2a Ilieva et al] 


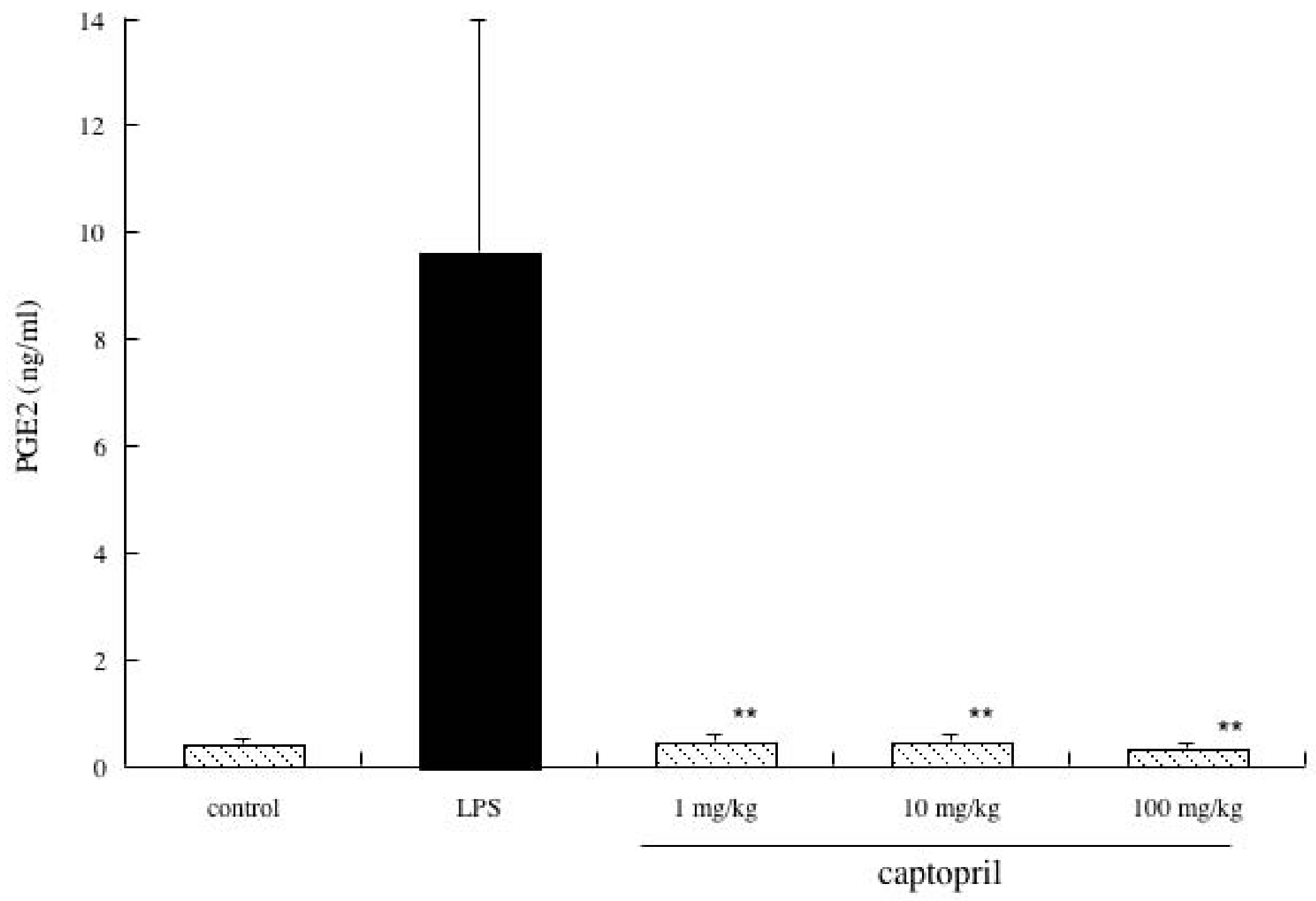

[Fig. 2b Ilieva et al] 


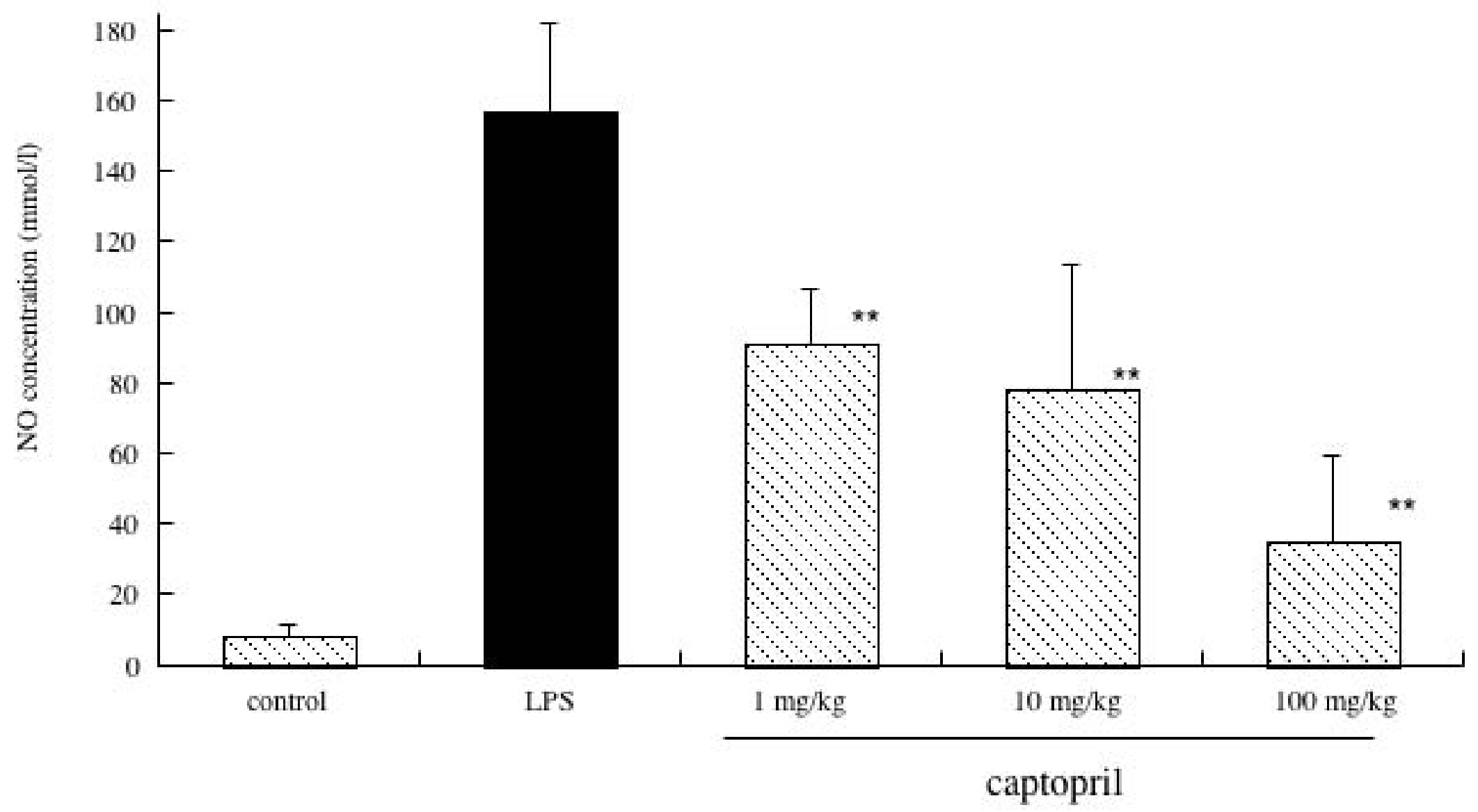

[Fig. 2c Ilieva et al] 


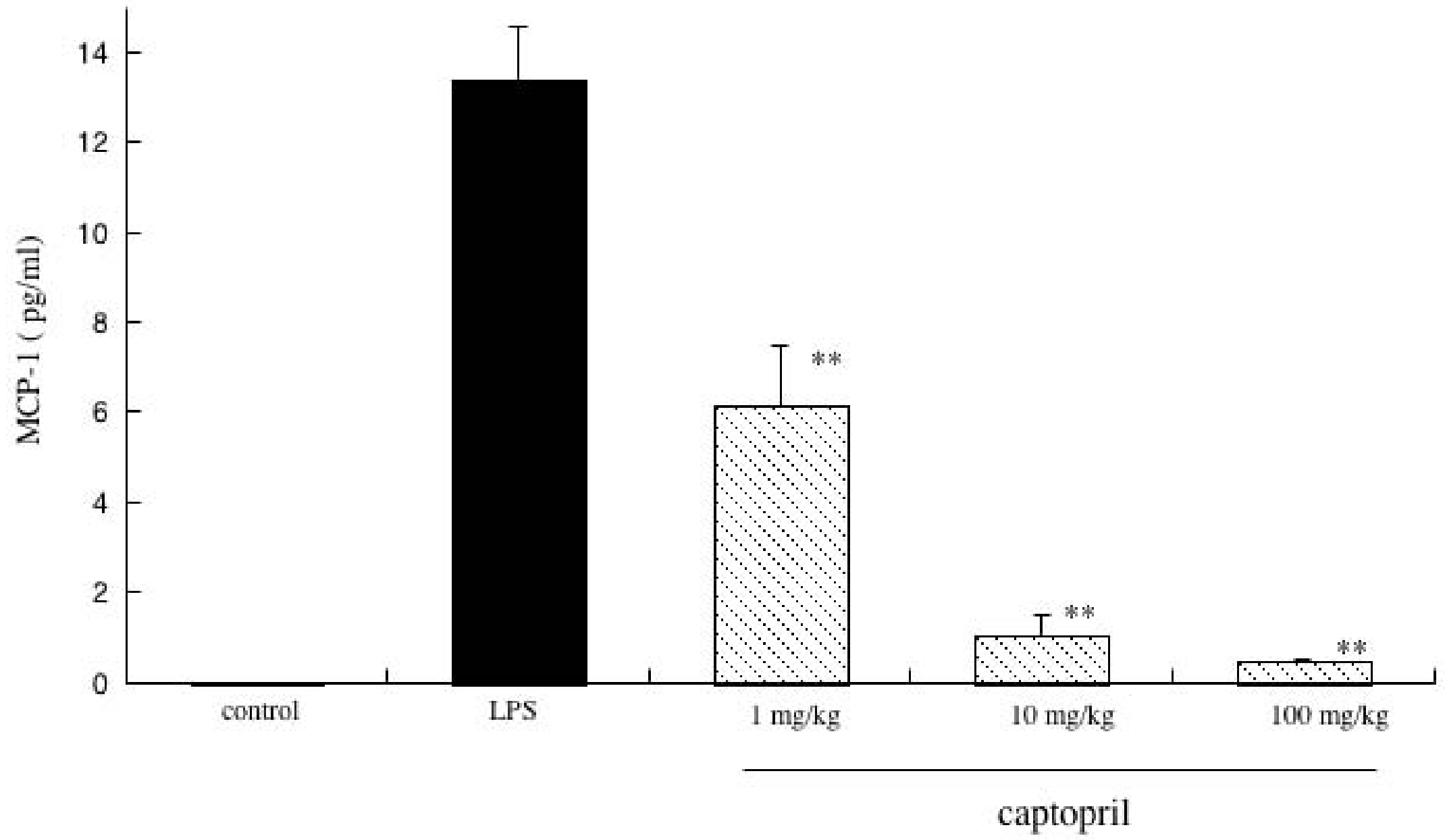

[Fig.3 Ilieva et al] 
a

21

$-\infty,-\infty$

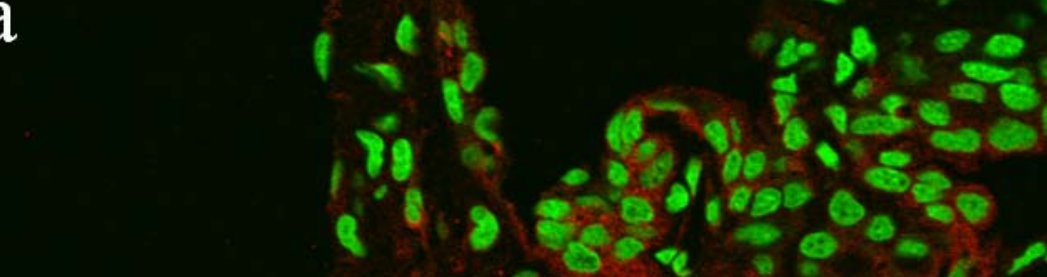

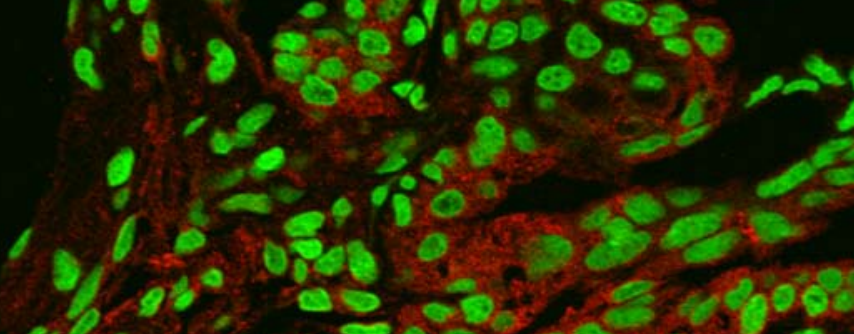

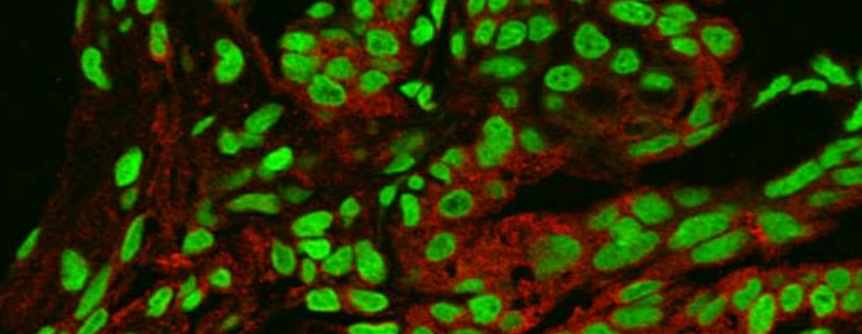

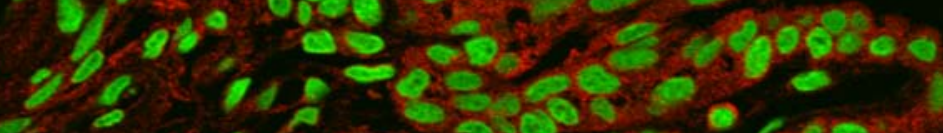
$1.00 \% 40$

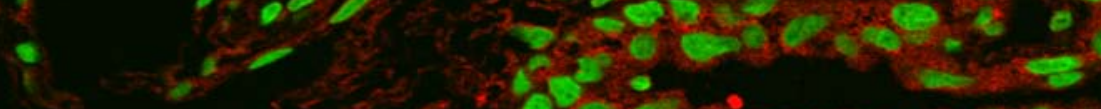

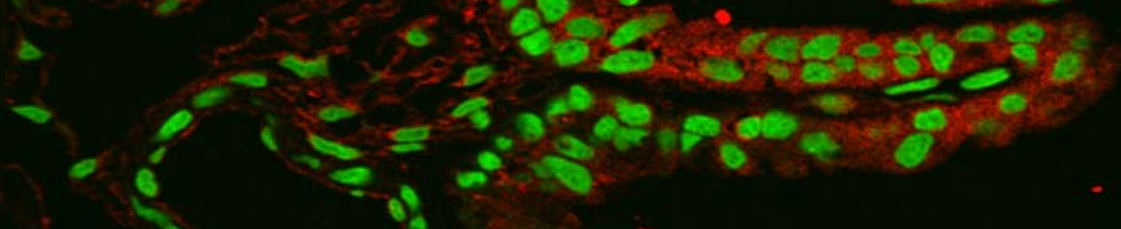

d

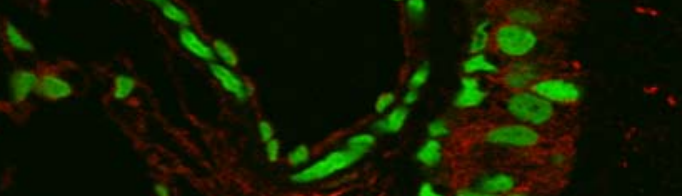

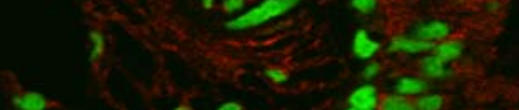

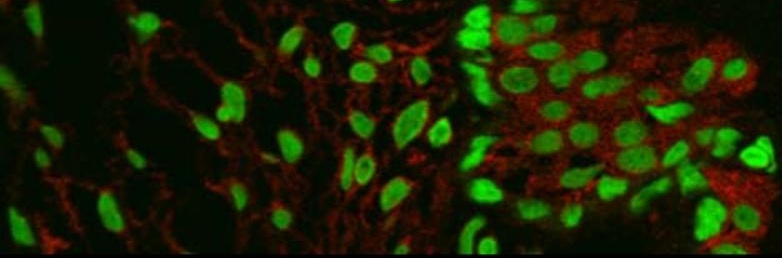


b

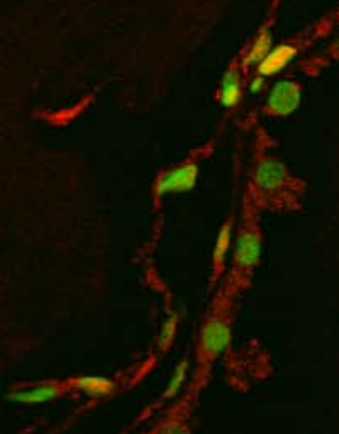

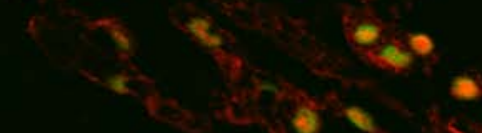

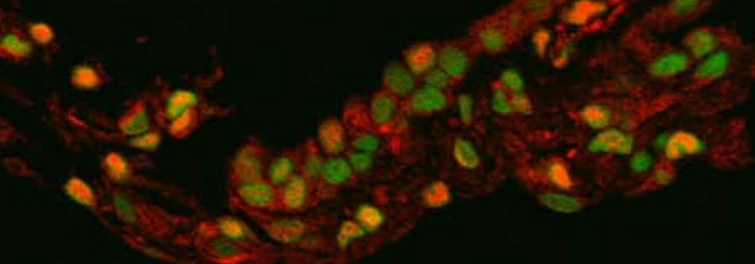




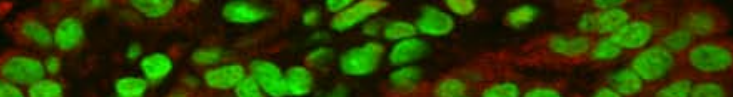

C

$\sum_{\rightarrow \infty}$

if 4?

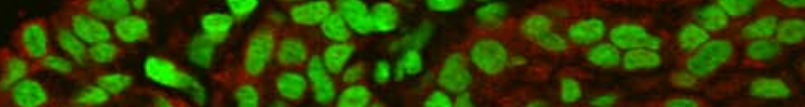

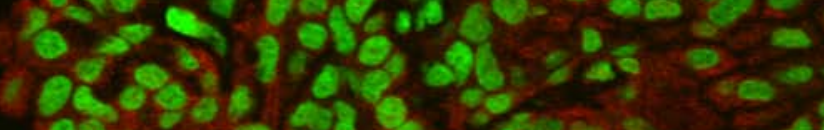

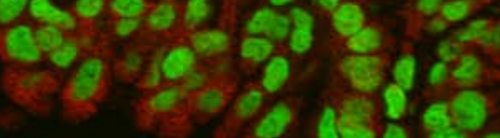

a) 5 .

8

1 20 wis:

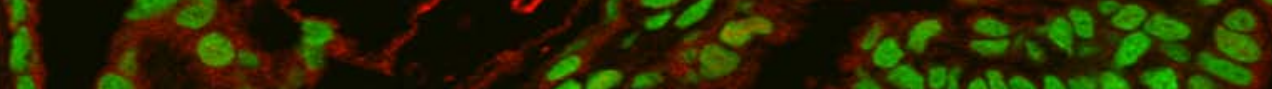
I. $16801,20 \% 5$

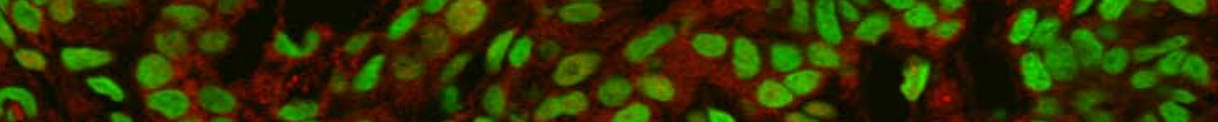

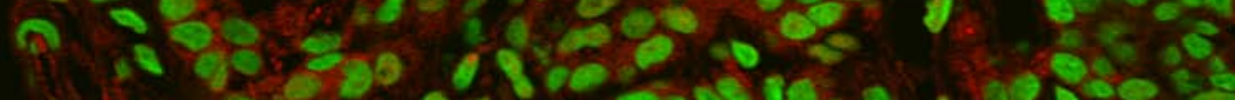

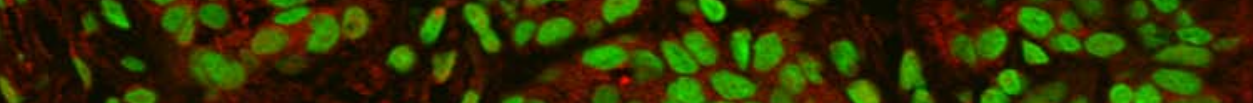

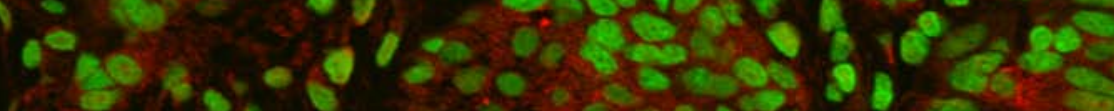

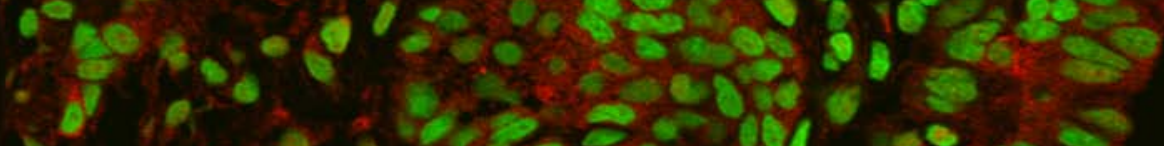
$\because 40.0735050$

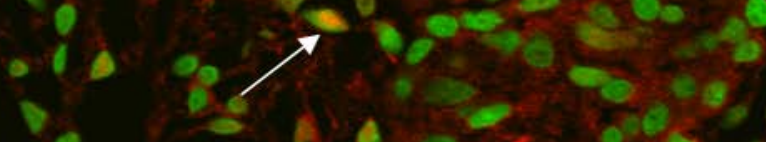

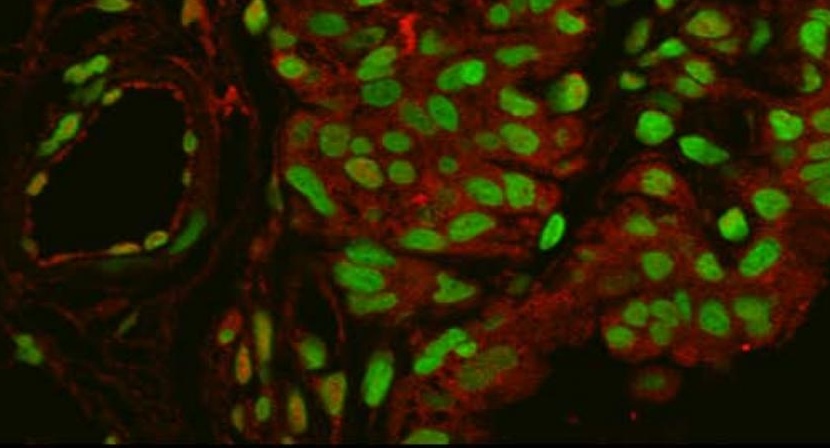




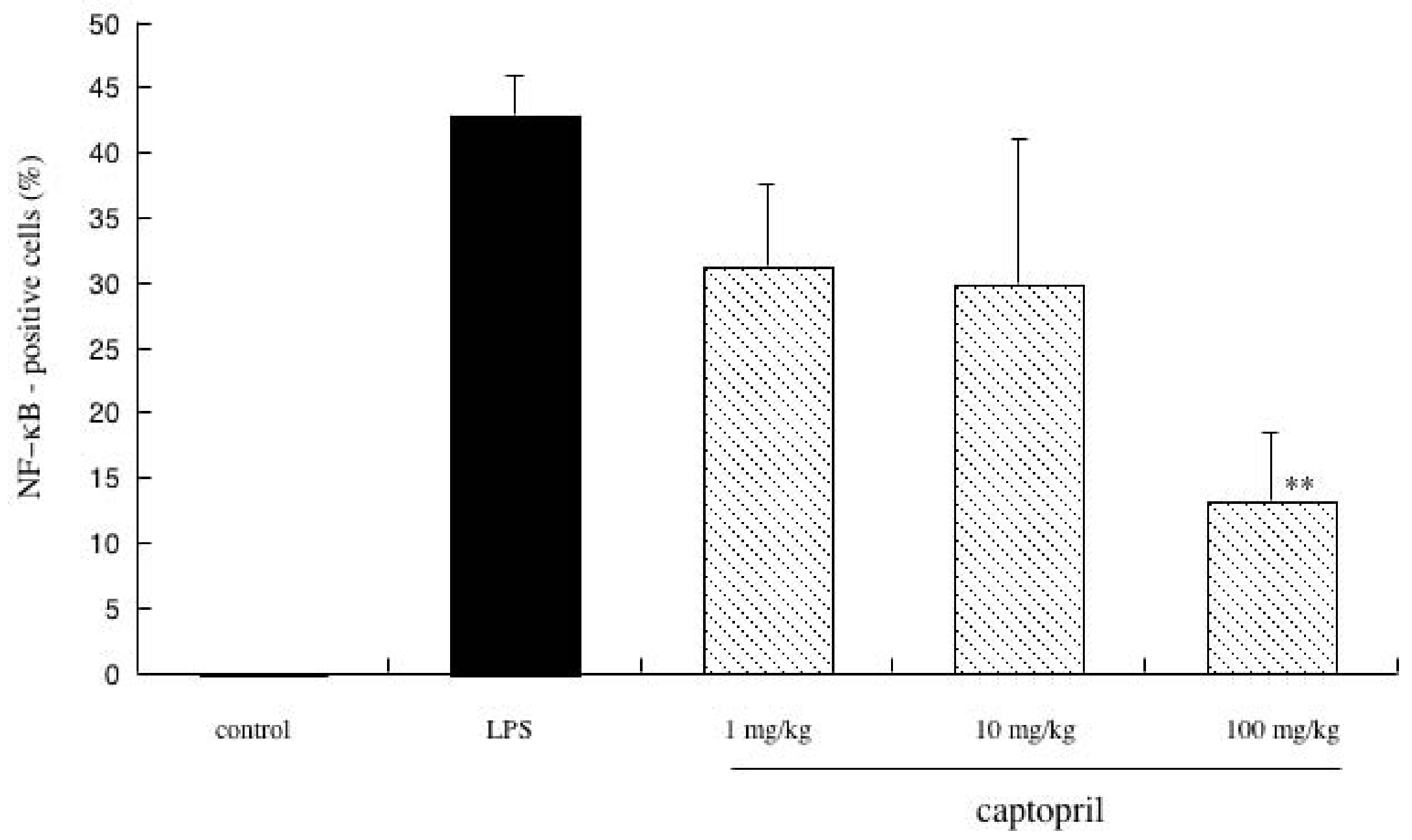

[Fig. 4B Ilieva et al] 